\section{Jurnal Manajemen Bisnis}

Program Pascasarjana Universitas Muhammadiyah Tangerang
ISSN: 2302-3449 I e-ISSN: 2580-9490

Vol. 8I No. 2, hal 105-114

\title{
STRATEGI PEMASARAN PENGEMBANGAN INVESTASI BISNIS KOMPONEN BAHAN BAKU PADA PT. EGA NUSANTARA
}

\author{
EKO YOGI PRASETYO ${ }^{1}$, AEP RUHANDI ${ }^{2}$ \\ Universitas Muhammadiyah Tangerang \\ Eko.yogy.prasetyo05@gmail.com, aepruhandi@gmail.com
}

\begin{tabular}{lr}
\hline Keyword & \\
\hline $\begin{array}{l}\text { Marketing } \\
\text { analysis, } \\
\text { external } \\
\text { factors }\end{array}$ & $\begin{array}{c}\text { Strategy, SWOT } \\
\text { envirnal and }\end{array}$ \\
&
\end{tabular}
Abstract

PT. Ega Nusantara is one of the medium voltage panel maker companies in Indonesia. Where the majority of products are used by PT. PLN throughout Indonesia. PT. Ega Nusantara seeks to improve its competitiveness by adding new products outside the panel, namely current transformers, voltage transformers, bushings, capacitive deviders, insulators and load break switches. The whole component is a panel supporting component made from epoxy resin. To expand, a study of marketing strategies is needed using SWOT analysis and identifies the company's internal and external environmental factors that influence marketing strategies.

Indonesia's current economic growth requires the support of reliable energy supplies including electricity. Electricity needs will increase in line with economic development and population growth. Based on the RUPTL (Electricity Supply Business Plan) PT. PLN, Indonesia have't get the electricity of all regions could become potential investment in the electricity sector. The electrification ratio up to 2016 was 91.16\%. When compared to Singapore it's already 100\%, Brunei Darussalam 99.7\%, Malaysia 99.0\%, Thailand 99.3\%, and Vietnam 98.0\%. In addition to the condition of the electrification ratio that has not reached $100 \%$, the condition of the electricity supply in the national electricity system also reflects the imbalance between supply and demand, with these conditions, of course, there are still opportunities for investors to participate in electricity supply businesses.

C2019 JMB, All right reserved

\section{PENDAHULUAN}

\section{Latar Belakang Masalah}

Suatu perusahaan yang bergerak dibidang perakitan komponen (assembly) sangat rentan sekali terkena krisis ketersediaan raw material (komponen) jika mayoritas komponen yang dirakit adalah barang impor. Penguatan nilai mata uang dolar terhadap rupiah selalu menjadi kendala bagi pengusaha lokal dalam produksi, dimana harga barang impor menjadi sangat mahal walaupun harga komponen dalam nilai mata uang dolar tetap, karena pembelian 
yang dilakukan oleh pelanggan (customer) menggunakan mata uang rupiah. Selain dari pada itu masalah lain yang dihadapi pada barang impor adalah indent barang impor yang membutuhkan waktu yang lama yaitu sekitar 12 bulan dari pemesanan, juga kesulitan retur barang impor yang cacat.

Berangkat dari masalah-masalah tersebut salah satu solusinya adalah perusahaan berinvestasi untuk membuat komponen itu sendiri, pengembangan suatu bisnis dengan menambah jenis produk lain yang mendukung raw material (komponen) memiliki bayak sekali keuntungan. Beberapa keuntungan yang didapat adalah memperkuat ketersediaan komponen itu sendiri, mengurangi ketergantungan dari supplier, mengurangi impor, meminimalisir kesalahan pembuatan komponen, kemudahan retur komponen, riset dan Pengembangan produk menjadi mumpuni, memperkuat brand produk eksisting, peningkatan nilai kandungan lokal (TKDN) serta peningkatan nilai keuntungan ekonomis dari komponen serta produk perakitan itu sendiri.

Di lain sisi selain untuk pemenuhan kebutuhan individu perusahaan, terdapat nilai ekonomi dari pengembangan produk tersebut. Produk komponen juga dapat dijual ke PT. PLN atau pun perusahaan swasta lainnya. Mengingat kebutuhan tenaga listrik akan semakin meningkat sejalan dengan perkembangan ekonomi dan pertumbuhan penduduk. Setiap perusahaan, baik yang bergerak di bidang produk ataupun jasa, mempunyai tujuan untuk tetap hidup dan berkembang. Kondisi pertumbuhan bisnis sekarang ini cukup tinggi, dimana dapat dilihat dari tumbuhnya perusahaan perusahaan dengan produk yang sejenis sebagai pesaing, sehingga akan terjadi persaingan dalam memperebutkan pangsa pasar dan konsumen. Dalam hal ini perusahaan hendaknya mengetahui pasar, dimana produk atau jasa yang diproduksi akan di tawarkan atau di pasarkan.

Strategi merupakan hal yang sangat penting bagi perusahaan dimana strategi merupakan suatu cara mencapai tujuan dari sebuah perusahaan. Menurut Swastha strategi adalah serangkaian rancangan besar yang menggambarkan bagaimana sebuah perusahaan harus beroperasi untuk mencapai tujuan.

Pemasaran menurut Kothler dan Amstrong adalah sebuah proses social manajerial, dimana individu-individu dan kelompokkelompok memperoleh apa yang mereka butuhkan dan mereka inginkan, melalui penciptaan dan pertukaran produk serta nilai dengan pihak lain. Adapun tujuan dari pemasaran adalah untuk memahami keinginan dan kebutuhan konsumen agar produk atau jasa sesuai bagi konsumen sehingga produk atau jasa tersebut dapat terjual dengan sendirinya.

Oleh karena itu pemasar dituntut untuk dapat memahami permasalahan pokok di bidangnya. Dapat memberikan gambaran yang jelas dan terarah tentang apa yang dilakukan perusahaan dan menyusun strategi agar dapat mencapai tujuan perusahaan. Strategi pemasaran mempunyai peranan penting untuk mencapai keberhasilan usaha, oleh karena itu bidang pemasaran berperan besar dalam merealisasikan rencana usaha. Hal ini dapat dilakukan, jika perusahaan ingin mempertahankan dan meningkatkan penjualan produk atau jasa yang mereka produksi. Dengan melakukan penerapan strategi pemasaran yang akurat melalui pemanfaatan peluang dalam meningkatkan penjualan, sehingga posisi atau kedudukan perusahaan di pasar dapat ditingkatkan atau dipertahankan. Sehubungan dengan hal tersebut pelaksanaan pemasaran modern dewasa ini mempunyai peranan yang besar sebagai penunjang langsung terhadap peningkatan laba perusahaan. Strategi pemasaran harus dapat memberi gambaran yang jelas dan terarah tentang kegiatan yang akan dilakukan perusahaan dalam memaksimalkan setiap kesempatan atau peluang pada beberapa pasar sasaran.

Kajian strategi pemasaran untuk melakukan ekspansi tersebut diperlukan idetifikasi faktor-faktor lingkungan internal dan eksternal perusahaan yang mempengaruhi strategi pemasaran .Berdasarkan penjelasan tersebut, maka penulis tertarik untuk melakukan riset dengan mengambil judul "STRATEGI PEMASARAN PENGEMBANGAN 
INVESTASI BISNIS KOMPONEN BAHAN BAKU PADA PT. EGA NUSANTARA".

\section{Rumusan Masalah}

Dari pemaparan latar belakang sebelumnya, maka dirumuskan permasalahan yang akan diteliti sebagai berikut :

1. Bagaimana Segmentasi, targeting dan positioning yang diterapkan PT. Ega Nusantara terhadap peluang dan daya saing pasar?

2. Bagaimana Bauran pemasaran yang diterapkan PT. Ega Nusantara terhadap peluang dan daya saing pasar?

3. Menganalisis Posisi Internal (IFAS) dan Eksternal (EFAS) pada PT. Ega Nusantara berdasar pada diagram kartesius ?

4. Menganalisa Alternatif Strategi pemasaran yang diterapka PT. Ega Nusantara berdasarkan Matrix SWOT?

\section{Tujuan Penelitian}

Tujuan Penelitian yang ingin dicapai dalam penulisan ilmiah ini adalah untuk mengetahui strategi pemasaran pengembangan investasi bisnis komponen bahan baku pada PT. Ega Nusantara apakah sudah tepat sesuai sasaran dan strategi alternatif yang diperlukan PT. Ega Nusantara .

\section{Manfaat Penelitian} adalah

Manfaat yang diharapkan dari penelitian ini

1. Sebagai bahan pertimbangan bagi perusahaan dalam mengambil keputusan khususnya mengenai kebijakan strategi pemasaran

2. Hasil penelitian ini dapat dijadikan rujukan dan referensi dalam melakukan penelitian lebih lanjut mengenai strategi pemasaran

\section{II.TINJAUAN PUSTAKA}

\section{Strategi Pemasaran}

Philip Kotler (2004) menyatakan bahwa Strategi pemasaran adalah proses manajerial untuk mengembangkan dan menjaga agar tujuan, keahlian, dan sumber daya organisasi sesuai dengan peluang pasar yang terus berubah. Tujuan perencanaan strategis adalah untuk membentuk serta menyempurnakan usaha bisnis dan produk perusahaan sehingga memenuhi target laba dan pertumbuhan.

Pemasaran memegang peranan yang penting dalam proses perencanaan strategis. Manajemen pemasaran memberikan sumbangan fungsional paling besar dalam proses perencanaan strategis dengan peran kepemimpinan dalam mendefinisikan misi bisnis, menganalisa situasi lingkungan, persaingan, dan situasi bisnis.mengembangkan tujuan sasaran dan strategi serta mendefinisikan rencana produk, pasar distribusi dan kualitas untuk menerapkan strategi usaha.

Suatu perusahaan yang maju didalam memperoleh keuntungan dari kegiatan bisnis dan beberapa unit-unit bisnis, tergantung kepada sejauh mana strategi pemasaran diterapkan dengan baik oleh pelaku bisnis atau pengambil keputusan dalam mensosialisasikan item-item penting dari kegiatan pemasarannya. Strategi pemasaran yang maju dan berkembang senantiasa memperhatikan adanya unsur menarik perhatian segmen pasar atau pangsa

pasar yang produktif dalam kegiatan pemasaran. Selain itu berupaya untuk menempatkan posisi pemasaran yang strategis dalam memperoleh keuntungan dan berupaya untuk mencapai target dari realisasi yang diterapakannya.

Menurut Sofyan Assauri (2008) strategi pemasaran adalah serangkaian tujuan dan sasaran, kebijakan dan aturan yang memberi arah kepada usaha-usaha pemasaran perusahaan dari waktu ke waktu, pada masing-masing tingkatan dan acuan serta alokasinya, terutama sebagai tanggapan perusahaan dalam menghadapi lingkungan dan keadaan persaingan yang selalu berubah, Oleh karena itu, penentuan strategi pemasaran harus didasarkan atas analisa lingkungan dan internal perusahaan melalui analisa keunggulan dan kelemahan perusahaan, serta analisa kesempatan dan ancaman yang dihadapi perusahaan dari lingkungannya.

Berdasarkan pendapat diatas, maka strategi pemasaran pada hakekatnya merupakan rencana yang menyeluruh dan 
terpadu tentang pemasaran, yang memuat secara rinci tentang rangkaian kegaiatan yang harus dijalankan perusahaan untuk tujuan pemasaran. Strategi pemasaran suatu perusahaan harus didasarkan atas analisis lingkungan internal dan eksternal perusahaan. Analisis internal perusahaan merupakan analisis keunggulan dan kelemahan perusahaan, sedangkan analisis eksternal merupakan analisis atas berbagai faktor luar yang mempengaruhi perusahaan. Dengan analisis-analisis tersebut akan memungkinkan manajemen perusahaan dapat mengambil keputusan dalam kegiatan pemasaran yang strategis.

Menurut Olson Jerry (2013) Strategi pemasaran dari sudut pandang analisis konsumen adalah serangkaian rangsangan ditempatkan pada lingkungan konsumen yang dirancang untuk memengaruhi afeksi, kognisi, dan perilaku konsumen. Stimulus ini melibatkan produk, merek, kemasan, iklan, kupon, kartu kredit, label harga, komunikasi para penjual, dan pada beberapa kasus, suara (musik), wewangian (parfum), dan petunjuk sensori lainnya.

Gugup Kismono, (2012) mengungkapkan Strategi Pemasaran adalah rencana untuk memilih dan menganalisis target pasar, mengembangkan, dan memelihara bauran pemasaran yang dapat memuaskan kebutuhan konsumen. Langkah-langkah pengembangan strategi pemasaran umumnya mencakup perencanaan strategi, pemilihan pasar sasaran, mendesain bauran pemasaran, dan menganalisis lingkungan pemasaran.

Berdasarkan konsep diatas, yang dimaksud dengan strategi pemasaran dalam penelitian ini adalah serangkaian rangsangan ditempatkan pada lingkungan konsumen yang dirancang untuk memengaruhi afeksi, kognisi, dan perilaku konsumen dengan langkah-langkah yang mencakup perencanaan strategi, pemilihan pasar sasaran, mendesain bauran pemasaran, dan menganalisis lingkungan pemasaran.

\section{Bauran Pemasaran (Marketing Mix)}

Bauran Pemasaran (Marketing Mix) menurut Philip Kotler (2012) adalah seperangkat alat pemasaran terkontrol yang dipadukan oleh perusahaan untuk menghasilkan respon yang diinginkan pasar sasaran.

Kevin Keller (2012), mendefinisikan bauran pemasaran sebagai seperangkat alat pemasaran perusahaan menggunakan untuk mengejar tujuan pemasarannya di pasar sasaran.

1. Produk (Product)

Suatu yang dapat ditawarkan ke pasar untuk mendapatkan perhatian, agar produk yang dijual mau dibeli, digunakan atau dikonsumsi yang dapat memenuhi suatu keinginan atau kebutuhan dari konsumen.

2. Harga (Price)

Sejumlah nilai yang ditukarkan konsumen dengan manfaat dari memiliki atau menggunakan produk atau jasa yang nilainya ditetapkan oleh pembeli dan penjual melalui tawar menawar, atau ditetapkan oleh penjual untuk satu harga yang sama terhadap semua pembeli.

3. Tempat (Place)

Tempat diasosiasikan sebagai saluran distribusi yang ditujukan untuk mencapai taget konsumen. Sistem distribusi ini mencakup lokasi, transportasi, pergudangan, dan sebagainya.

4. Promosi (Promotion)

Sebagai salah satu cara pemasaran untuk mengkomunikasikan dan menjual suatu produk kepada konsumen yang berpotensi

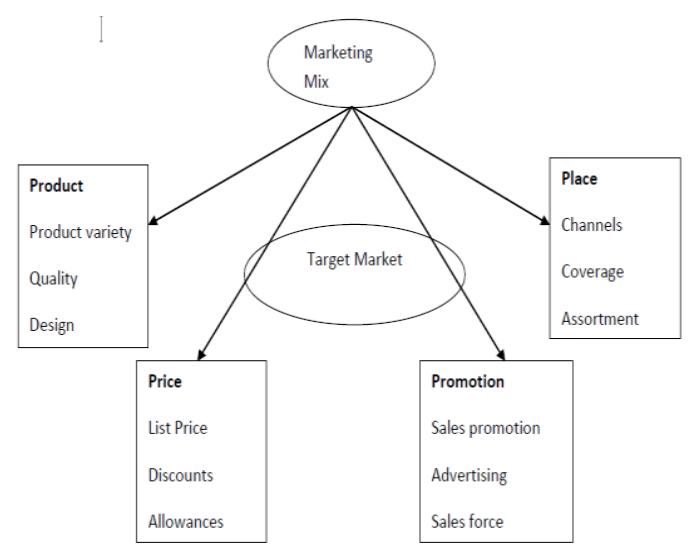

Gambar 1.1 Marketing Mix 


\section{METODOLOGI PENELITIAN}

\section{Metode Penelitian}

Bentuk penelitian yang digunakan yaitu penelitian dalam bentuk deskriptif dengan pendekatan kualitatif dengan mempergunakan data primer yang diperoleh melalui survei, peneliti ini memiliki dua jenis data:

\section{Data Primer}

Data primer adalah data langsung yang diperoleh dari manajer, supervisor internal perusahaan dan eksternal perusahaan yang berkompetensi memberikan keterangan secara langsung dengan cara wawancara langsung

\section{Data Sekunder}

Data sekunder adalah data yang diperoleh dari konsumen tetap PT. PLN dan perusahaan kompetitor, kemudian dari studi pustaka dengan mempelajari berbagai tulisan, buku dan tesis yang berhubungan dengan penelitian ini. Data Sekunder, merupakan data yang diperoleh dari dokumentasi perusahaan.

Untuk lebih jelas bentuk penelitian di gambarkan sebagai berikut :

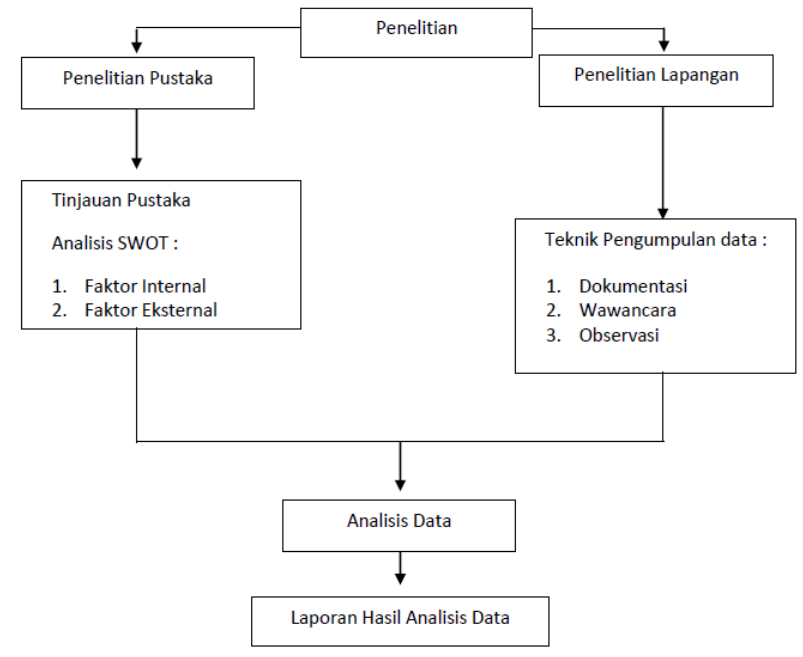

Gambar 2.1. Skema Penelitian

\section{Teknik Pengumpulan Data}

Untuk memperoleh data atau informasi sebagai bahan analisis dalam penyusunan penelitian ini, maka ditempuh tiga teknik pengumpulan data yaitu :

a. Obsevasi, menurut Kusuma (1987:25) adalah pengamatan yang dilakukan dengan sengaja dan sistematis terhadap aktivitas individu atau obyek lain yang diselidiki. Adapun jenis-jenis observasi tersebut diantaranya yaitu observasi terstruktur, observasi tak terstruktur, observasi partisipan, dan observasi nonpartisipan. Salah satu metode yang dilakukan sebagai pengamatan dan pencatatan secara sistematik terhadap gejala yang tampak pada objek penelitian. Pengamatan dilakukan untuk memperoleh data tentang aktivitas pada PT. Ega Nusantara sebagai sasaran objek penelitian.

b. Wawancara, dalam teknik pengumpulan menggunakan wawancara hampir sama dengan kuesioner. Wawancara itu sendiri dibagi menjadi 3 kelompok yaitu wawancara terstruktur, wawancara semi-terstruktur, dan wawancara mendalam (in-depth interview).

Namun disini peneliti memilih melakukan wawancara mendalam, ini bertujuan untuk mengumpulkan informasi yang kompleks, yang sebagian besar berisi pendapat, sikap, dan pengalaman pribadi, Sulistyo-Basuki (2006:173).

Untuk menghindari kehilangan informasi, maka peneliti meminta ijin kepada informan untuk menggunakan alat perekam. Sebelum dilangsungkan wawancara mendalam, peneliti menjelaskan atau memberikan sekilas gambaran dan latar belakang secara ringkas dan jelas mengenai topik penelitian. Wawancara dilakukan secara langsung kepada beberapa orang informan. Mereka meliputi pemilik perusahaan, manager riset dan pengembangan dan manager sales marketing PT. Ega Nusantara.

c. Dokumen menurut Sugiyono, (2009:240) merupakan catatan peristiwa yang sudah berlalu, yaitu dimaksudkan untuk memperoleh data tertulis dari PT. Ega Nusantara, berupa: sejarah singkat perusahaan, strukur organisasi dan data-data (dokumen) tentang pemasaran yang diharapkan dapat menjadi acuan dalam menganalisa permasalahan dalam penelitian ini. 


\section{Teknik Analisis Data}

Pada penelitian ini digunakan salah satu alat analisa yaitu metode SWOT (Strenght, Weakness, Opportunity, Threats). SWOT adalah suatu bentuk analisis didalam manajemen perusahaan atau dalam organisasi yang secara sistematis dapat membantu dalam usaha penyusunan suatu rencana yang matang untuk mencapai tujuan, baik tujuan jangka pendek maupun panjang.

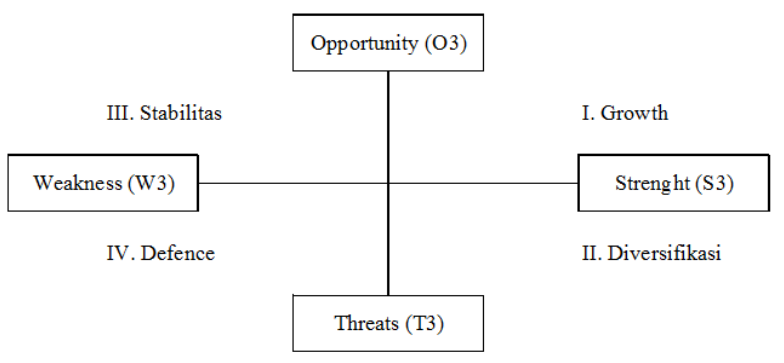

Gambar 3.2 Diagram Matrix SWOT

\begin{tabular}{|c|c|c|}
\hline IFAS & \begin{tabular}{|l}
- Strengths (S) \\
Tentukan Faktor-faktor \\
Peluang Internal
\end{tabular} & $\begin{array}{l}\text { - Weakness (W) } \\
\text { Tentukan Faktor-faktor } \\
\text { Ancaman Eksternal }\end{array}$ \\
\hline - Opportunities $(\mathrm{O})$ & - Strategi S-O & - Strategi W-O \\
\hline $\begin{array}{l}\text { Tentukan Faktor-faktor } \\
\text { Peluang Eksternal }\end{array}$ & $\begin{array}{l}\text { Ciptakan Strategi yang } \\
\text { menggunakan kekuatan untuk } \\
\text { memanfaatkan peluang } \\
\text { (Agresif) }\end{array}$ & $\begin{array}{l}\text { Ciptakan strategi yang } \\
\text { meminimalkan kelemahan } \\
\text { untuk memanfaatkan } \\
\text { peluang (Turn Around) }\end{array}$ \\
\hline $\begin{array}{l}- \text { Threats (T) } \\
\text { Tentukan Faktor-faktor } \\
\text { Ancam an Eksternal }\end{array}$ & $\begin{array}{l}\text { - Strategi S-T } \\
\text { Ciptakan strategi yang } \\
\text { menggunakan kekuatan untuk } \\
\text { mengatasi ancaman } \\
\text { (diversivikasi) }\end{array}$ & $\begin{array}{l}\text { - Strategi W-T } \\
\text { Ciptakan strategi } \\
\text { meminimalkan kelemahan } \\
\text { dan menghindari ancaman }\end{array}$ \\
\hline
\end{tabular}

Gambar 3.3 Matrik Aplikasi SWOT

\section{HASIL PENELITIAN}

\section{Hasil Analisis Peluang Pemasaran}

Hingga akhir tahun 2014, rasio elektrifikasi Indonesia mencapai $84,35 \%$. Angka ini meningkat $17,20 \%$ dibandingkan tahun 2010 yang baru mencapai $67,15 \%$. Sedangkan kapasitas pembangkit tenaga listrik mengalami penambahan sebesar 17.405 MW dibandingkan tahun 2010 sebesar 36.180 MW. Pemerintah secara berkesinambungan juga berupaya untuk memperbaiki bauran energy pembangkitan tenaga listrik dengan menekan secara maksimal penggunaan BBM dalam bauran energi pembangkitan tenaga listrik. Realisasi pemakaian bahan bakar minyak (BBM) menurun dari $22 \%$ pada tahun 2010 menjadi 9,70\% pada tahun 2014 . Pada akhir tahun 2019, diharapkan, rasio elektrifikasi Indonesia mencapai 97,35\%, meningkat $13 \%$ dibanding tahun 2014. Untuk meningkatkan angka rasio elektrifikasi, pemerintah juga tetap melaksanakan program-program pro rakyat yang pendanaannya melalui APBN seperti program listrik perdesaan yang membangun jaringan distribusi hingga pelosok-pelosok desa, serta program instalasi listrik gratis untuk masyarakat tidak mampu dan nelayan.

Kebutuhan pasokan listrik 5 tahun ke depan diperkirakan membutuhkan tambahan kapasitas terpasang pembangkit listrik sebesar 42,9 GW sehingga kapasitas terpasang dari tahun 2014 sebesar 53,6 GW menjadi 96,5 GW dengan penggunaan bahan bakar minyak ditargetkan sebesar $2,04 \%$. Untuk mendukung penyaluran tenaga listrik tersebut maka dibutuhkan tambahan jaringan transmisi sekitar 46.000 kms sampai akhir tahun 2019.

- Proyek 10.000 MW Tahap I (FTP1)

dimulai tahun 2006 terdiri dari 37 proyek yang ditargetkan selesai

seluruhnya pada tahun 2009. Namun dalam pelaksanaannya banyak

mengalami kendala sehingga target penyelesaiannya mengalami

keterlambatan. Berbagai kendala yang dihadapi antara lain: permasalahan engineering(desain/drawing, commissi on ing), non-engineering (perijinan / rekomendasi, pengadaan /pembebasan lahan, impor barang, pendanaan) dan masalah konstruksi (material/equipment, lack of management, eskalasi). Sampai dengan akhir 2014, FTP 1 yang telah berhasil diselesaikan sebesar 7.401 MW dan selebihnya 2.526 MW diperkirakan selesai tahun 2015-2016.

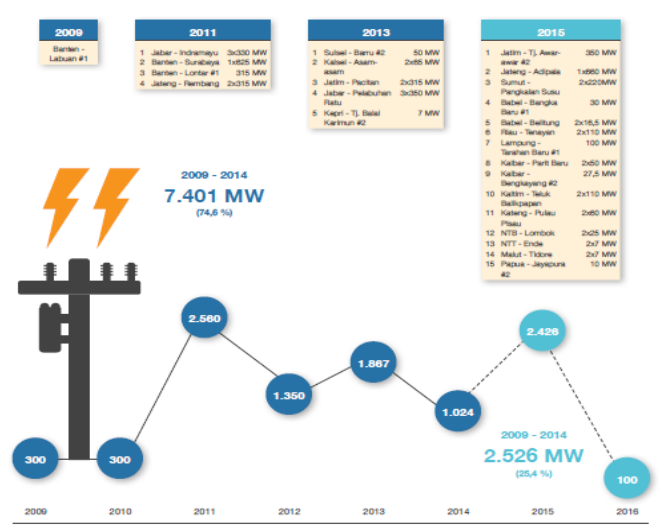

Gambar 4.1. Proyek 10.000 MW Tahap 1 
- $\quad$ Proyek 10.000 MW Tahap II (FTP2)

dicanangkan oleh Pemerintah sebagai upaya untuk mempercepat diversifikasi energi untuk pembangkit tenaga listrik ke non-BBM, mengoptimalkan pemanfaatan potensi panas bumi dan tenaga air serta sekaligus memenuhi kebutuhan tenaga listrik yang terus meningkat FTP 2 terdiri atas pembangkit yang menggunakan energi terbarukan

(38\%) yakni panas bumi dan tenaga air. Selain itu, pembangkit yang menggunakan batubara dengan teknologi yang lebih efisien dan gas $(62 \%)$. Pelaksana proyek pembangkit didominasi oleh swasta $(68 \%)$ dan

PLN (32\%). FTP 2 terdiri dari 76 proyek dengan total kapasitas 17.918

MW, dengan rincian Proyek PLN sebanyak 17

proyek (5.749 MW) dan proyek swasta sebanyak

59 proyek (12.169 MW). Sampai dengan tahun

2014, FTP 2 telah berhasil diselesaikan sebesar

55 MW yaitu dari PLTP Patuha di Pengalengan,

Jawa Barat.

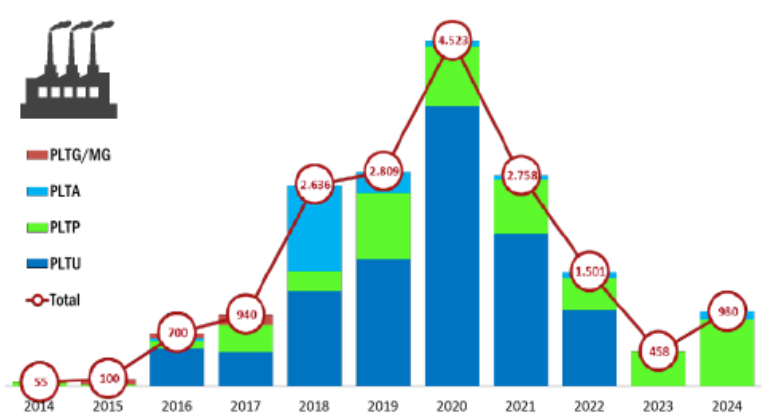

Gambar 3.2 Proyek 10.000 MW Tahap II

Investasi ketenagalistrikan mencakup pembangunan pembangkitan, transmisi, gardu induk, gardu distribusi dan jaringan distribusi serta usaha penunjang ketenagalistrikan. Peran Pemerinah dalam investasi di subsector ketenagaslitrikan cukup besar. Lebih dari Rp 3 triliun per tahun dialokasikan APBN untuk infrastruktur pembangkit listrik. Target investasi ketenagalistrikan tahun 2015 sebesar US\$ 11,2 miliar dan meningkat dimana pada 2019 direncanakan sekitar US\$ 15,9 miliar utamanya karena pembangunan Program Ketenagalistrikan 35.000 MW
Berdasarkan hasil wawancara dengan beberapa pihak internal maupun eksternal di Kantor PT. Ega Nusantara, penerapan strategi pemasaran yang dilakukan PT. Ega Nusantara yaitu dengan memilih merumuskan pasar yang dituju dengan menggunakan segmentasi, targeting dan positioning. Selain itu dengan mengembangkan marketing mix atau bauran pemasaran $7 \mathrm{P}$ yang terdiri dari empat unsur utama yaitu produk, harga, distribusi, promosi dan 3 unsur tambahan yaitu people, sarana fisik dan proses, yang bertujuan untuk menarik pembeli dan mempertahankan pelanggan yang sudah ada.

Untuk lebih jelasnya mengenai strategi pemasaran pada PT. Ega Nusantara, dapat diuraikan sebagai berikut:

\section{Segmentasi}

Segmentasi memiliki peran penting dalam sebuah perusahaan karena segmentasi memungkin perusahaan untuk lebih fokus dalam mengalokasikan sumber daya. Membagi pasar menjadi segmensegmen akan memberikan gambaran bagi perusahaan untuk menetapkan segmen mana yang akan dilayani.

Selain itu segmentasi memungkinkan perusahaan mendapatkan gambaran yang lebih jelas mengenai peta kompetisi serta menentukan posisi pasar perusahaan.

Segmentasi merupakan dasar untuk menentukan komponen-komponen strategi. Segmentasi yang disertai dengan pemilihan target pasar akan memberikan acuan dalam penentuan positioning.

Segmentasi juga dapat dikatakan merupakan faktor kunci untuk mengalahkan pesaing, dengan memandang pasar dari sudut yang unik dan cara yang berbeda dari yang dilakukan pesaing. PT. Ega Nusantara dalam menentukan segmentasi pasarnya lebih memfokuskan pada Industri kelistrikan tegangan menengah, karena industri tegangan menengah memiliki prospek yang baik, apalagi dengan melihat energi listrik merupakan kebutuhan dasar manusia modern. Seluruh kehidupan kita saat ini 
sangat bergantung pada kebutuhan listrik yang cukup dan handal. Seiring meningkatnya konsumsi listrik, kebutuhan pasokan listrik di Indonesia terus meningkat. Berdasarkan asumsi pertumbuhan ekonomi ratarata sekitar $6,7 \%$ per tahun (sesuai RPJMN 2015-2019), maka Indonesia membutuhkan tambahan kapasitas pembangkit ratarata $7 \mathrm{GW}$ per tahun dan tambahan jaringan transmisi rata-rata $9.000 \mathrm{kms}$ per tahun.

\section{Targetting}

Sasaran pasar adalah suatu kelompok konsumen yang agak homogen, kepada siapa perusahaan ingin melakukan pendekatan guna dapat menariknya (appeal) untuk membeli produk yang di pasarkan. Setelah mengevaluasi segmen-segmen yang berbeda, perusahaan dapat mempertimbangkan dua pola pemilihan target pasar, yaitu:

\section{a. Spesialisasi produk}

Spesialisasi pengembangan produk komponen yang ditawarkan oleh PT. Ega Nusantara adalah :

\section{Current Transformer}

Merupakan Komponen utama pada Panel yang berfungsi sebagai sensing arus untuk membaca arus tegangan menengah pada panel.

\section{Voltage Transformer}

Merupakan Komponen utama pada Panel yang berfungsi sebagai sensing tegangan untuk membaca tegangan menengah pada panel.

\section{Capacitive Devider \& Isolator}

Merupakan komponen pendukung pada panel yang berfungsi sebagai sensing tegangan dan juga support busbar.

\section{Bushing}

Merupakan komponen pada panel yang berfungsi sebagai isolasi busbar agar busbar tidak tersentuh oleh tangan maupun bendabenda lainnya serta memperpanjang jarak creapege.

\section{Load Break Switch}

Merupakan komponen utama pada panel yang berfungsi sebagai saklar pemutus berbeban.

\section{b. Spesialisasi pasar}

Terdapat 2 sasaran (target market) PT. Ega Nusantara yaitu :

1. PT. PLN (Persero), merupakan perusahaan yang mengatur ketenagalistrikan di Indonesia, jalur pemasarannya adalah melalui procurement PT. PLN dengan pengujian dan sertifikasi di PUSERTIF dan PUSLITBANG.

2. Swasta, untuk swasta terbagi menjadi 3, yaitu Perusahaan Panel Maker, kontraktor elektrik dan rekanan PLN di daerah, beberapa perusahaan panel maker yang menjadi target market komponen epoxy : ABB, Schneider, Siemens, Panelindo, Pura Mayungan, 3Phase Engineering, Fuji, Duta Engineering, GAE, GE, dll

\section{Positioning}

Menurut Kartajaya (2006) positioning adalah menyangkut bagaimana suatu bisnis mendapatkan kepercayaan dari konsumennya. Positioning juga sebagai janji yang diberikan produk, merek, dan perusahaan kepada pelanggan.Melakukan positioning berarti berusaha menempatkan merek di bagian pasar agar merek tersebut mendapat sambutan positif dibandingkan produk pesaingnya.

Positioning produk adalah cara produk ditetapkan oleh konsumen berdasarkan atribut penting yang dimiliki produk dalam ingatan konsumen dibandingkan dengan pesaing. Menurut Kotler dan Amstrong (2003) ada beberapa alternatif strategi positioning, yaitu Positioning langsung dibandingkan dengan pesaing.

PT. Ega Nusantara memiliki kepercayaan yang baik dimata pelanggan, alasan tersebut membuat posisi PT. Ega Nusantara diakui sebagai perusahaan yang memiliki kualitas produk yang mumpuni.

Sedangkan positioning langsung dibandingkan pesaing, PT. Ega Nusantara memiliki beberapa pesaing pada produk epoxy resin, berikut beberapa perusahaan pesaing :

1. PT. Trafoindo Prima Perkasa

Produk yang ditawarkan adalah Current Transformer, Voltage Transformer, Capacitive Devider dan Isolator. Perusahaan ini merupakan perusahaan besar dengan share market sebesar $50 \%$ populasi produknya di seluruh Indonesia dan sudah memegang hampir seluruh panel maker di Indonesia. Pelanggan 
terbesarnya adalah PLN dan Schneider Indonesia, untuk Schneider Indonesia sendiri sudah membuat joint dengan PT. Trafoindo untuk produk Current Transformer, Voltage Transformer

2. PT. Bambang Djaja

Produk yang ditawarkan adalah Current Transformer, Voltage Transformer, Capacitive Devider. Perusahaan ini merupakan perusahaan local yang besar dengan share market sebesar 30\% populasi produknya di seluruh Indonesia dan sudah memegang hampir seluruh panel maker di Indonesia. Pelanggan terbesarnya adalah PLN

3. PT. Esitas Indonesia Transformer

Produk yang ditawarkan adalah Current Transformer, Voltage Transformer. Perusahaan ini merupakan perusahaan PMA asal Turki. Dengan membawa nama besar Esitas Turki yang sudah malang melintang di Eropa, namun perusahan ini masih dalam kategori berkembang share market sebesar $10-20 \%$ populasi produknya di seluruh Indonesia dan sudah memegang hampir seluruh panel maker di Indonesia. Pelanggan terbesarnya adalah PLN dan Schneider Indonesia, untuk Schneider Indonesia sendiri sudah membuat joint dengan PT. Esitas untuk produk Current Transformer, Voltage PT. Esitas Indonesia Transformer.

\section{Bauran Pemasaran}

Setelah memutuskan seluruh segmentasi, targeting dan positioning, PT. Nusantara selanjutnya merencanakan atau merumuskan bauran pemasaran

(marketing mix) yang memiliki 7 variabel sebagai berikut :

\section{Produk}

Produk adalah setiap apa saja yang ditawarkan kepasar untuk mendapatkan perhatian pembeli, pemakai atau konsumen yang dapat memenuhi keinginan atau kebutuhan pemakainya. Strategi produk yang di lakukan PT. Ega Nusantara ialah dengan menggunakan bahan-bahan yang berkualitas tinggi. Untuk desain tiap produk di buat compact, rigid dan simpel yang dapat digunakan pada setiap panel tapi mudah dalam pemasangannya dilapangan. Membuat produk dengan merek atau nama sesuai bahan dasar dan fungsi produk sama dengan produk PT. Ega Nusantara yang telah di PLN PUSERTIF dan PUSLITBANG .

\section{Price (Harga)}

Harga suatu barang atau jasa merupakan penentu bagi permintaan pasarnya, harga dapat mempengaruhi posisi persaingan perusahaan dan juga mempengaruhi market share-nya. Bagi perusahaan, harga akan memberikan hasil dengan menciptakan sejumlah pendapatan dan keuntungan bersih. Harga suatu barang juga dapat mempengaruhi program pemasaran perusahaan. PT. Ega Nusantara menetapkan harga berdasarkan 2 faktor, yaitu biaya total + margin yang menjadikan nya harga jual. Tetapi harga jual yang di keluarkan Ega Nusantara sesuai. dengan kualitas barang yang di berikan dengan harga yang kompetitif dan harga yang pantas.

\section{Place (Tempat/Distribusi)}

Pelanggan Ega Nusantara berada di hampir seluruh daerah di Indonesia. Agar barang sampai ke pembeli dengan cepat, strategi distribusi yang dilakukan oleh PT. Ega Nusantara adalah dengan berkerjasama dengan perusahaan rekanan PLN diseluruh Indonesia dan perusahaan membuat stok produk. PT Ega Nusantara bekerja sama dengan salah satu perusahaan pengiriman kilat melalui darat, udara dan laut yaitu SAP Express.

\section{Promotion (Promosi)}

Kegiatan promosi dalam PT. Ega Nusantara adalah kegiatan yang sangat penting di dalam memasarkan produknya. Kegiatan inilah yang bagaimana membuat konsumen tertarik dengan produk yang kita punya. Berikut beberapa strategi promosi yang dilakukan oleh PT. Ega Nusantra yaitu :

Website www. eganusantra.co.id, Katalog 
produk, Door to door sales ,Seminar Universitas

\section{People (Manusia)}

Manusia dalam hal ini adalah karyawan perusahaan, PT Ega Nusantara sangat selektif untuk memilih SDM yang berkompeten di bidangnya. Perusahaan memiliki beberapa syarat minimal untuk calon karyawan baru di PT Ega Nusantra. Karena bila merekrut yang sudah berpengalaman diharapkan akan semakin mengembangkan perusahaan.

\section{Physical Evidence (Sarana Fisik)}

PT. Ega Nusantara memiliki bangunan pabrik yang besar dengan teknologi tinggi, kantor pusat yang cukup megah di daerah Jakarta Pusat. Memiliki fasilitas dan peralatan kantor memadai yang memberikan kenyamanan untuk para karyawan untuk bekerja. Diharapkan menambah produktifitas para karyawan dan meningkatkan pendapatan. Khususnya untuk Supervisor tiap wilayah diberikan sarana mobil operasional yang digunakan untuk menghampiri tiap konsumen untuk menawarkan produk, dan untuk konsumen yang sudah membeli supervisor menjaga hubungan baik agar terus membeli produk.

\section{Process (Proses)}

PT. Ega Nusantara memiliki system proses pemesanan sebagai berikut:

a. Proses pemesanan : konsumen melakukan pemesanan melalui marketing atau sales man/girl lalu marketing membuat form permintaan barang kepada gudang.

b. Gudang : menerima form permintaan barang dari marketing, lalu di cek apakah barang yang di pesan stokny tersedia atau tidak.

c. Jika barang kosong, gudang melakukan permintaan barang kepada pabrik.

d. Bila barang tersedia, gudang memberikan informasi kepada logistik agar dibuatkan surat jalan dan faktur pembelanjaan.

e. Setelah barang siap dan surat-surat siap, selanjutnya barang akan di serahkan kepada mitra pengiriman perusahaan yaitu SAP. f. Pengiriman kurang lebih 2-3 hari tergantung jauhnya tujuan. Setelah sampai barang di cek bila barang aman proses pembayaran dilakukan hingga jatuh tempo 30 hari dari tanggal faktur terbit.

g. Jika ada kerusakan barang maka akan ada proses retur melalui pengecekan barang oleh perusahaan dan bila disetujui maka barang akan segera di proses kembali dari proses pemesanan.

\section{Analisa Faktor Internal \& Eksternal}

Analisis SWOT atau TOWS adalah alat teknik penelitian kualitatif untuk mengidentifikasi berbagai faktor secara sistematis untuk merumuskan strategi dalam meningkatkan tingkat volume penjualan produk sebuah perusahaan. Analisis ini didasarkan pada logika yang dapat memaksimalkan kekuatan (Strength) dan peluang (oppurtunities), namun secara bersamaan dapat meminimalisir kelemahan (weakness) dan ancaman (threat). Model yang dipakai pada tahap ini terdiri dari matriks faktor strategi internal dan matriks faktor strategi eksternal.

Berdasarkan hasil perhitungan, faktor internal kekuatan yang dimiliki PT. Ega Nusantra lebih besar dari faktor kelemahan nya yaitu sebesar 1.96, yang dimana angka 1.96 merupakan selisih dari total kekuatan sebesar 2.54 dengan total kelemahan sebesar 0.58, dan untuk faktor eksternal peluang yang dimiliki PT. Ega Nusantara lebih besar dari faktor ancaman nya yaitu sebesar 1.9 yang dimana merupakan selisih dari total peluang sebesar 2.5 dengan total ancaman sebesar 0.6. Dari perhitungan tersebut dapat diperoleh formulasi strategi pemasaran yang sesuai .

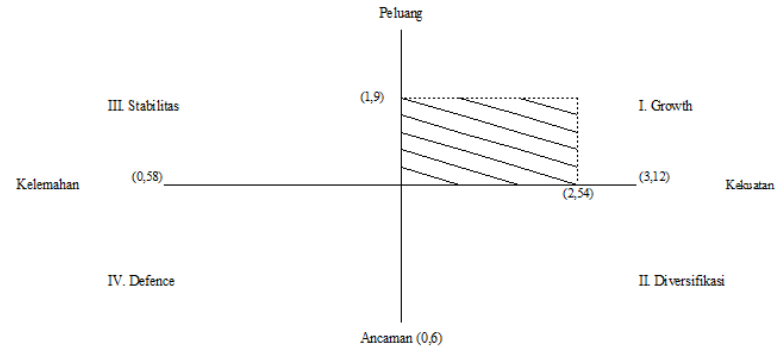

Gambar 4.1 Diagram Kartesius 
Berdasarkan diagram kartesius diatas, sangat jelas menujukkan bahwa PT Ega Nusantara telah berada pada jalur yang tepat yaitu di kuadran 1 yang menunjukkan bahwa perusahaan masih tergolong perusahaan yang berkembang. PT. Ega Nusantara memang masih tergolong perusahaan berkembang dikarenakan baru berdiri 8 tahun jika di bandingkan dengan perusahaan lain dibidang sejenis. Meskipun masih dalam perusahaan berkembang, PT.Ega Nusantara harus memperhatikan peluang dan ancaman baik dari internal maupun eksternal. Dengan memperhatikan faktor-faktor yang sudah dijelaskan tentu akan meningkatkan pertumbuhan pemasaran perusahaan yang akan meningkatkan penjualan.

\section{KESIMPULAN DAN SARAN}

\section{A. Kesimpulan}

Dari penelitian di atas maka dapat diambil kesimpulan :

1. Dalam melakukan strategi pemasaran PT. Ega Nusantara menerapkan segmentasi, targetting dan positioning dengan benar dan tepat. Lalu PT. Ega Nusantara menggunakan Bauran Pemasaran (Marketing Mix) 7P yang terdiri dari strategi produk (product), strategi harga (price), strategi penentuan lokasi (place), strategi promosi (promotion), strategi manusia (people), strategi sarana fisik (physical evidence), dan proses (process).

2. Berdasarkan analisis internal dan eksternal perusahaan beserta diagram Cartesius dapat diperoleh bahwa yang menjadi strategi utama dari PT. Ega Nusantara adalah strategi Growth. Dimana PT. Ega Nusantara dapat mempertahankan dan meningkatkan ekspansi produk agar pelanggan terus percaya pada produk PT. Ega Nusantara. Lalu memperdalam jalinan dengan mitra guna menciptakan hubungan yang baik serta membuat promosi yang menarik untuk meningkatkan penjualan produk.

\section{Saran}

Berdasarkan pengamatan penulis mengenai strategi pemasaran produk yang di terapkan PT.
Ega Nusantara, maka adapun saran yang ingin penulis sampaikan adalah berikut :

1. Untuk meningkatkan pengembangan, PT. Ega Nusantra terus meningkatkan kualitas produk guna menarik kepercayaan agar terus digunakan oleh konsumen dan membuat diferensiasi produk. Dengan pengembangan produk baru akan menimbulkan ketertarikan pelanggan pada inovasi produk tersebut. Terus meningkatkan kegiatan promosi semenarik mungkin dari promosi harga maupun membuat iklan guna membuat konsumen tertarik pada produk perusahaan yang akan meningkatkan volume penjualan.

2. Peneliti menyadari masih banyak kekurangan dalam penulisan, maka diharapkan untuk peneliti selanjutnya dapat melanjutkan penelitian ini dengan mengukur dari segi aspek yang berbeda dan metodelogi yang berbeda.

\section{DAFTAR PUSTAKA}

Briefcase Book Edukasi Profesional Syariah, Dasar dan Strategi Pemasaran Syariah. Cet-1, 2005. Jakarta: Renaisan.

Bungin.Burhan, Metode Penelitian Kualitatif. 2004. Jakarta: PT. Raja Grafindo Persada.

Ginting.Nembah F. 2011. Hartimbul, Manajemen Pemasaran, Bandung: Yrama Widya.

Gitosudarmo.Indriyo，2000. Manajemen Pemasaran, Edisi II BPFE, Yogyakarta : Erlangga..

Gitosudarmo.Indriyono, 2001.

Manajemen Strategis, Yogyakarta: BPFE-Yogyakarta.

Gitosudarmo.Indriyo. 2008. Pengantar Bisnis Edisi 9. Yogyakarta: BPFE. 
Hayani.Nurahmi, 2012. Manajemen Pemasaran Bagi Pendidikan Ekonomi. Pekanbaru: Suska Press,

Hermawan. 2002. Marketing. Jakarta : Gramedia.

Kartajaya.Hermawan dan M. Syakir Sula, Syariah Marketing, Cet. Ke-1, 2006. Bandung: Mizan..

Kasmir. 2003. Manajemen Perbankan. Jakarta : PT. Raja Grafindo Persada.

Kasmir. 2010. Pemasaran Bank. Jakarta: Kencana.

Kasmir dan Jakfar. 2003. Studi Kelayakan Bisnis, Jakarta : Prenada Media.

Khotijah.Siti. 2004. Smart Strategy of Marketing, Bandung: ALFABETA.

Kotler.Philip dan Gray Amstrong Penerjemah Alexander Sindoro. 2004. Edisi ke-9, Jilid 1, Dasar-Dasar Pemasaran, Jakarta : PT Indeks.

Kotler.Philip dan Armstrong,. 1997. Edisi 2 Jilid 1 Prinsip-Prinsip Pemasaran, Jakarta : Erlangga.

Kotler.Philip dan Keller, Manajemen Pemasaran, Jakarta: PT.Indeks, Edisi 12, Jilid 1.

Kotler.Philip, 2002. Manajemen Pemasaran, Jakarta:Prehallindo, Jilid 1, Edisi Milenium .

Kotler.Philip dan Garry Armstrong, 2008. Prinsip-prinsip Pemasaran, Jakarta: Erlangga, Jilid ke-1

Kotler.Philip. 2006. Manajemen Pemasaran, Jakarta:PT. Indeks Gramedia, Jilid 1 dan 2, Edisi ke-11.

Kotler.Philip dan Amstrong. 2012. PrinsipPrinsip Pemasaran, Edisi ke-13, Jilid ke-1, Jakarta : Erlangga
Kotler. Philip dan Kevin Lane Keller, 2008. Manajemen Pemasaran, Edisi Ketiga Belas Jilid 1, Erlangga.

Moleong.Lexy J., 2011. Metodelogi Penelitian Kualitatif. Cetakan 29. Bandung: PT. Remaja Rosdakarya.

Rangkuti.Freddy, 2008. Analisis SWOT Teknik Membedah Kasus Bisnis, Jakarta :PT.Gramedia Pustaka Utama.

Render.Barry dan Jay Heizer, 2001. Prinsip-prinsip Manajemen Operasi, Jakarta:Salemba Empat.

Siagian.Dergibson dan Sugiarto. 2000. Metode Statistik untuk Bisnis dan Ekonomi, Jakarta: PT Gramedia Pustaka Utama.

Sugiono, 2005. Memahami Penelitian Kualitatif, Bandung:ALFABETA.

Sunarto. 2004. Manajemen Pemasaran, Yogyakarta : AMUS.

Sunyoto.Danang, 2012 Dasar-Dasar Manajemen Pemasaran, Yogyakarta: CAPS Cet- 1.

Sunyoto. 2007. Marketing Strategy Top Brand Indonesia, Yogyakarta : Andi,

Swastha.Basu, $2007 \quad$ Manajemen Pemasaran. Jakarta: Liberty Edisi ke-8, Cetakan ke-8.

Tim Penyusunan Departemen Pendidikan dan Kebudayaan RI, Kamus Besar Bahasa Indonesia, Jakarta:Balai Pusatka,1997.

Tjiptono.Fandy, 2004. Strategi Pemasaran, Yogyakarta : Andi Press.

Tripomo.Tedjo dan Udan, 2005. Manajemen Strategi, Bandung: Rekayasa Sains.

Umar.Husein, 2007. Metode Penelitian Untuk Skripsi dan Tesis Bisnis, Jakarta:Rajawali Press cet ke-2. 
